\title{
CONTRIBUTIONS TO THE BRYOPHYTE FLORA OF THE ALCSÍK BASIN, ROMANIA
}

\author{
Beáta PAPP ${ }^{1 *}$, Ágnes SzAKÁLY ${ }^{2}$ and Zoltán TóTH ${ }^{3}$ \\ ${ }^{1}$ Department of Botany, Hungarian Natural History Museum, \\ H-1476 Budapest, Pf. 222, Hungary; * pappbea@bot.nhmus.hu \\ ${ }^{2}$ Danube Research Institute, Centre for Ecological Research, Hungarian Academy of Sciences, \\ H-2131 Göd, Jávorka Sándor u. 14, Hungary \\ ${ }^{3}$ Department of Plant Systematics, Ecology and Theoretical Biology, Eötvös Loránd University, \\ H-1117 Budapest, Pázmány Péter sétány 1/C, Hungary
}

Papp, B., Szakály, Á. \& Tóth, Z. (2015): Contributions to the bryophyte flora of the Alcsík Basin, Romania. - Studia bot. hung. 46(2): 55-68.

\begin{abstract}
A recent investigation on the bryophyte flora of the Alcsík Basin resulted in recording 70 bryophyte taxa ( 5 liverworts and 65 mosses). Although declining in some aspects, the area still preserves very valuable bryophyte vegetation rich in elements characteristic for fens and mires. Hamatocaulis vernicosus is the most valuable species recorded, a bryophyte included in the Bern Convention, in the European Union Habitats and Species Directive, and in the Red data book of European bryophytes. Several other rarities in SE Europe occur in the investigated area, including Breidleria pratensis, Dicranum bonjeanii, Drepanocladus polygamus, Philonotis marchica, P. caespitosa, Plagiomnium ellipticum, Polytrichum strictum, Scorpidium cossonii, Sphagnum spp., and Tomentypnum nitens. Some of these, such as Plagiomnium ellipticum or Tomentypnum nitens, are very abundant and represent the largest populations recently recorded in SE Europe.
\end{abstract}

Key words: Hamatocaulis vernicosus, rare species, Sphagnum, wetlands

\section{INTRODUCTION}

Romania has 19 Ramsar sites with a total area of $1,156,448$ ha designated as Wetlands of International Importance, that is $4.84 \%$ of the country's land surface. Not all wetlands of Romania are included in the Ramsar site system, one of these is the Csík Basin. When compared to the neighbouring countries, Hungary has 28 Ramsar sites with 233,927 ha, while Bulgaria has 11 Ramsar sites with 50,000 ha (http://www.ramsar.org).

The Csík Basin has been a very important wetland region in Romania, since almost $25 \%$ of the total area of fens was concentrated here. Unfortunately, these wetland complexes have been destroyed due to water regulation works started in the 1970s. Currently the small remnants of natural wetlands, hidden among agricultural fields, are legally protected and in 2007 these were declared Natura 2000 sites. However, this act has not been followed up by conservation manage- 
ment and the state of these wetlands is continuously declining (KEREKES 2010). Most of the botanical surveys concerning the Csík Basin were carried out before or a few years after the water regulation works begun (NYÁRÁDY 1929, POP 1938, 1960, Kristó 1958, Gergely and Rațiu 1973, Rațiu and Gergely 1974, 1975a, b, 1981, Coldea and Plămadă 1977, Rațiu 1980, Mititele and SánTHA-Elekes 1984, Gergely et al. 1988), and only a few recent investigations were conducted in the area, mainly dealing with human activities affecting the state of the wetlands (JAKAB et al. 2007, KereKes 2010).

In spite of a long tradition of bryology in the region - though mostly focusing on the high mountains of the surroundings - only a few reports are available regarding the Alcsík Basin (JAKAB et al. 2007). Among these the most interesting result is a record of Meesia hexasticha from Borsáros wetland, Sîncrăieni (Csíkszentkirály), identified by Ádám Boros from the material collected by Gyula Nyárády E. (Boros 1943b). The specimen was collected in 1925, but when investigating the same location in 1941 Boros did not find it again. His herbarium, deposited in the Hungarian Natural History Museum, Budapest (BP), on the other hand, contains a few (ca 30) other bryophyte specimens from the Alcsík Basin, including samples found around Sîncrăieni (Csíkszentkirály) (Boros 1941, 1943a), Sînsimion (Csíkszentsimon) (Boros 1941), Tuşnadu Nou (Újtusnád) (Boros 1942).

The present paper provides recent data on the bryophyte vegetation sampled during a field survey in 2013, carried out in the frame of a larger project aiming at the exploration of the flora and fauna occurring in the wetlands of the Alcsík Basin. Based on our findings, bryophyte conservation aspects are also discussed here.

\section{MATERIAL AND METHODS}

\section{Study area}

With an elevation range of 650-740 m, the Alcsík Basin is the southernmost part of the Csík Basin situated between Miercurea-Ciuc (Csíkszereda) and Băile Tuşnad (Tusnádfürdő) at the eastern foothills of the Hargita Mts (Fig. 1). These wetlands are fed by limonite (iron hydrogen carbonate) rich spring waters (the local name is "borvíz"). The river Olt is dividing the ca $18 \mathrm{~km}$ long and $10 \mathrm{~km}$ wide basin from north to south. On the flysch base the sediment layer is made up of andesite and is covered by black meadow-, peat-, and bog soils. The water table is high $(0-1.0 \mathrm{~m})$. The climate is montane with significant temperature inversions, strongly affecting the flora of these peatlands, with annual mean temperature of $5.9^{\circ} \mathrm{C}$ and average annual precipitation of $567 \mathrm{~mm}$ (KEREKES 2010).

Common wetland types that can be found in the area are peaty reedbed, transitional fen, tall herb community, grey willow scrub; while non-tussock tall 
sedge community, peat moss transition mire, rich fen, Molinia meadow, and alder swamp are rare (KEREKES 2010).

\section{Methods}

The investigation was carried out in August 2013. Romanian botanist colleagues, involved in researching the higher plant flora and vegetation, have previously surveyed the territory and provided us very detailed descriptions and GPS coordinates of the important wetland sites making our work more efficient. Our work plan mainly focused on wetlands and source areas, but in some cases specimens were collected from artificial rock walls or volcanic rocks found around the wet places.

The voucher specimens are preserved in the Herbarium of the Hungarian Natural History Museum, Budapest (BP). The nomenclature for liverworts follows GROLle and LONG (2000), and for mosses Hill et al. (2006).

To evaluate the results from nature conservation aspect, the following literature sources were used: the Red data book of European bryophytes (ECCB 1995), the Checklist and the red list of the bryophytes of Romania (§̧TEFĂNUT, and Goia 2012), the Bryophyte red list of Serbia and Montenegro (SABOVLJEVIĆ et al. 2004), the Red list of the bryophytes of Bulgaria (NATCHEVA et al. 2006),

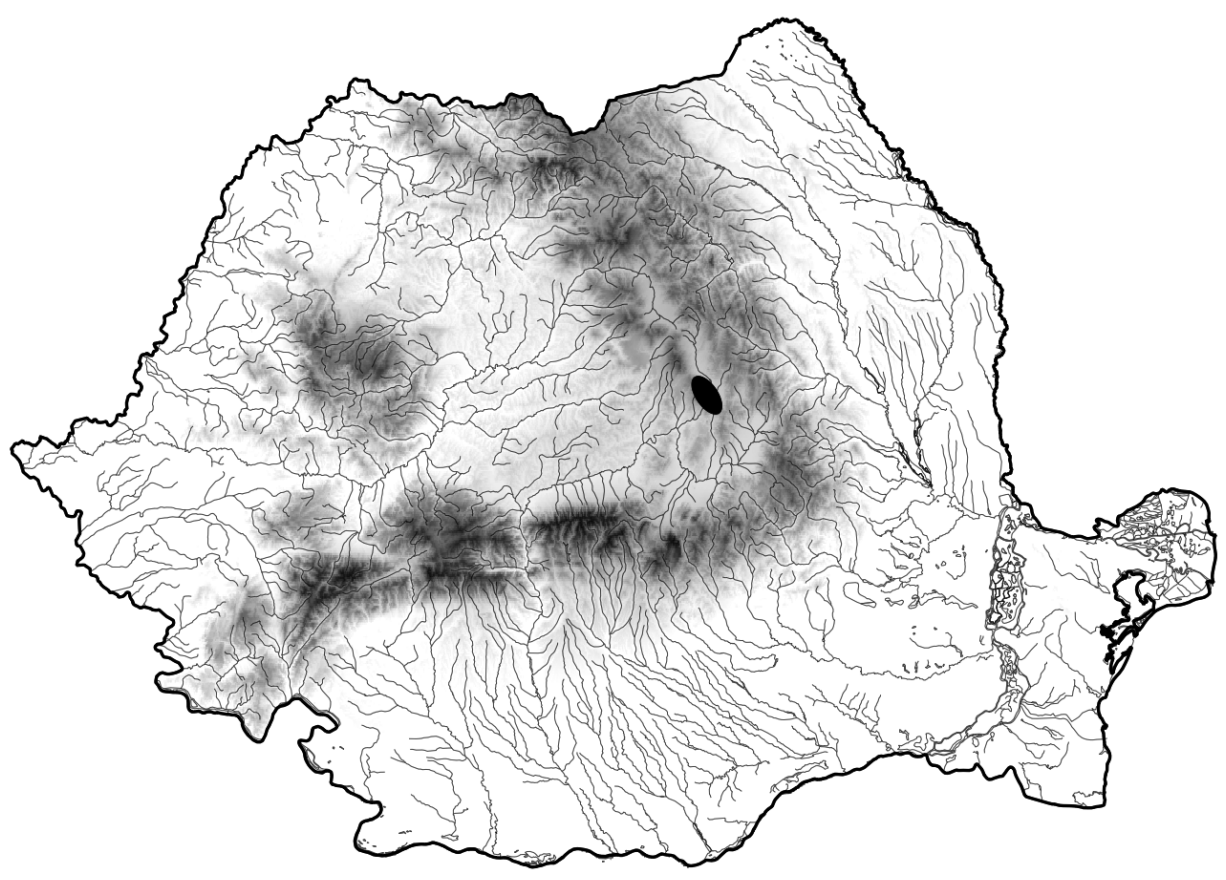

Fig. 1. Location of the investigated area. 
the checklist and the red list of the bryophytes of Hungary (PAPP et al. 2010) and Ukraine (IgNATOV et al. 2006). The symbols of the threat categories used are as follows. In the red list of the bryophytes of Romania (ŞTEFĂNUȚ and GoIA 2012), Bulgaria (NATCheva et al. 2006) and Hungary (PAPP et al. 2010): CR = critically endangered, EN = endangered, VU = vulnerable, NT = near threatened, $\mathrm{DD}=$ insufficiently known and $\mathrm{NE}=$ not evaluated; in the bryophyte red list of Serbia and Montenegro (SABovljević et al. 2004): EX = extinct, CR = critically endangered, $\mathrm{EN}=$ endangered, $\mathrm{VU}=$ vulnerable, $\mathrm{LR}=$ lower risk or near threatened and DD = data deficient.

\section{Site details}

1. Sîncrăieni (Csíkszentkirály), Borsáros wetland along river Olt, $46.31113^{\circ} \mathrm{N}, 25.83130^{\circ} \mathrm{E}, 650 \mathrm{~m}$, 31.07.2013.

2. Sîncrăieni (Csíkszentkirály), Alnetum and Salicetum cinereae at Borsáros, $46.31061^{\circ} \mathrm{N}, 25.83986^{\circ}$ E, $660 \mathrm{~m}, 31.07 .2013$.

3. Sînsimion (Csíkszentsimon), Honcsok wetland, $46.25369^{\circ} \mathrm{N}, 25.86644^{\circ} \mathrm{E}, 650 \mathrm{~m}, 31.07 .2013$.

4. Sînsimion (Csíkszentsimon), Felső Honcsok wetland, $46.25736^{\circ} \mathrm{N}, 25.85469^{\circ} \mathrm{E}, 660$ m, 31.07. 2013.

5. Sînsimion (Csíkszentsimon), Felső Honcsok wetland, $46.25616^{\circ} \mathrm{N}, 25.85697^{\circ} \mathrm{E}, 660$ m, 31.07 . 2013.

6. Sînsimion (Csíkszentsimon), Phragmitetum, $46.24438^{\circ} \mathrm{N}, 25.85458^{\circ} \mathrm{E}, 670 \mathrm{~m}, 01.08 .2013$.

7. Sînsimion (Csíkszentsimon), limonite spring cone, $46.24536^{\circ} \mathrm{N}, 25.85413^{\circ} \mathrm{E}, 670 \mathrm{~m}, 01.08 .2013$.

8. Sînsimion (Csíkszentsimon), $46.24727^{\circ} \mathrm{N}, 25.85436^{\circ} \mathrm{E}, 660 \mathrm{~m}, 01.08 .2013$.

9. Sînsimion (Csíkszentsimon), wetland at river Olt, $46.25205^{\circ} \mathrm{N}, 25.85277^{\circ} \mathrm{E}, 655 \mathrm{~m}, 01.08 .2013$.

10. Tuşnadu Nou (Újtusnád), Varsavész, wetland between the railway and river Olt, $46.19808^{\circ} \mathrm{N}$, $25.89091^{\circ} \mathrm{E}, 650 \mathrm{~m}, 01.08 .2013$.

11. Tuşnadu Nou (Újtusnád), Varsavész, wetland between the railway and river Olt, $46.19950^{\circ} \mathrm{N}$, 25.89002 $2^{\circ} \mathrm{E}, 650 \mathrm{~m}, 01.08 .2013$.

12. Tuşnadu Nou (Újtusnád), Nádasfürdő wetland, $46.17677^{\circ} \mathrm{N}, 25.90747^{\circ} \mathrm{E}, 740 \mathrm{~m}, 01.08 .2013$.

13. Sîntimbru (Csíkszentimre), ditches on the right side of river Olt, $46.28725^{\circ} \mathrm{N}, 25.86152^{\circ} \mathrm{E}, 660$ $\mathrm{m}$, 02.08.2013.

14. Sîntimbru (Csíkszentimre), ditches on the left side of river Olt, $46.28208^{\circ} \mathrm{N}, 25.86177^{\circ} \mathrm{E}, 660$ $\mathrm{m}$, 02.08.2013.

15. Sîntimbru (Csíkszentimre), wetland near Henter mansion, $46.27711^{\circ} \mathrm{N}, 25.86500^{\circ} \mathrm{E}, 660 \mathrm{~m}$, 02.08.2013.

16. Sîntimbru (Csíkszentimre), wetland near Henter mansion, $46.27652^{\circ} \mathrm{N}, 25.86541^{\circ} \mathrm{E}, 660 \mathrm{~m}$, 02.08.2013.

17. Sîntimbru (Csíkszentimre), wetland near a chapel, $46.27005^{\circ} \mathrm{N}, 25.85288^{\circ} 5 \mathrm{E}, 660 \mathrm{~m}$, 02.08.2013.

18. Sîntimbru (Csíkszentimre), $46.26413^{\circ} \mathrm{N}, 25.84980^{\circ} \mathrm{E}, 670 \mathrm{~m}, 02.08 .2013$.

19. Cetățuia (Csatószeg), limonite spring cone near river Olt, $46.22463^{\circ} \mathrm{N}, 25.87736^{\circ} \mathrm{E}, 660 \mathrm{~m}$, 02.08.2013.

20. Vrabia (Csíkverebes), Kiscsemő wetland, $46.21380^{\circ} \mathrm{N}, 25.88711^{\circ} \mathrm{E}, 655 \mathrm{~m}, 03.08 .2013$.

21. Tuşnad (Tusnád), $46.20722^{\circ} \mathrm{N}, 25.88797^{\circ} 5 \mathrm{E}, 655 \mathrm{~m}, 03.08 .2013$.

22. Tuşnadu Nou (Újtusnád), wetland opposite to Közép-stream, $46.18500^{\circ} \mathrm{N}, 25.88194^{\circ} \mathrm{E}, 650 \mathrm{~m}$, 03.08.2013. 


\section{RESULTS AND DISCUSSION}

During our fieldwork 70 bryophyte taxa ( 5 liverworts and 65 mosses) were collected. The complete list of bryophyte records can be found in Appendix 1.

18 species are included in the Red list of the bryophytes of Romania (ŞTEFĂNUȚ and Goia 2012). Among them one species, Hamatocaulis vernicosus is included in the Bern Convention and the European Habitat Directives, and in the Red data book of European bryophytes (ECCB 1995).

\section{General aspects of the bryophyte vegetation}

In the wetlands of the Alcsík Basin the most characteristic, abundant species are the following: Aulacomnium palustre, Brachythecium mildeanum, B. rutabulum, Bryum pseudotriquetrum, Calliergonella cuspidata, Climacium dendroides, Drepanocladus aduncus, Marchantia polymorpha, Plagiomnium elatum, P. ellipticum, Tomentypnum nitens. Aneura pinguis, Campylium stellatum, Dicranum bonjeanii, Fissidens adianthoides, Philonotis caespitosa are also important elements in some wetlands or at source areas. Most of these are indicators of wetlands of conservation importance, which means that these species by their mere presence refer to a greater level of conservation merit of the habitat. At two sites small populations of Sphagnum species (S. angustifolium, S. capillifolium, S. palustre, S. subsecundum) were also discovered. Breidleria pratensis, Drepanocladus polygamus, Polytrichum strictum, Scorpidium cossonii occur in small quantities in a few places. All of them are rare in SE Europe and have great importance for nature conservation. At source areas Lophocolea bidentata, Pellia endiviifolia, Cratoneuron filicinum, Dicranella varia, Didymodon tophaceus, Palustriella falcata, Philonotis marchica, Pohlia wablenbergii appear. The latter four mosses are also indicator species of source areas of great conservation value.

As a comparison of the bryophyte vegetation in the past and recent, it may be mentioned that Ádám Boros collected 15 species in the area in the 1940s (Boros 1941, 1942, 1943a) (Table 1). All of his findings were also collected during our research, and most of them are characteristic species of the wetlands of the Alcsík Basin even nowadays. The only difference is Sphagnum recurvum from Borsáros wetland at Sîncrăieni (Csíkszentkirály) (documented by Á. Boros), which probably is the same that we collected in the same place and identified as $S$. angustifolium. The Sphagnum recurvum group is a complex of closely related bryophytes that were only later separated (IsoviITA 1966, SмIтн 2004).

\section{Nature conservation value of the species recorded}

The most valuable species found is Hamatocaulis vernicosus. It is a boreal moss (DüLL 1985) occurring in oligotrophic wet grasslands, and is included in 
Table 1. Species collected by Ádám Boros in the Alcsík Basin between 1941 and 1943.

\begin{tabular}{|c|c|c|c|}
\hline & Sîncrăieni & Sînsimion & Tuşnadu Nou \\
\hline Abietinella abietina & + & & \\
\hline Aulacomnium palustre & + & + & + \\
\hline Brachythecium mildeanum & + & & \\
\hline Bryum pseudotriquetrum & + & & \\
\hline Calliergonella cuspidata & & + & + \\
\hline Climacium dendroides & + & & + \\
\hline Drepanocladus aduncus & + & & \\
\hline Hamatocaulis vernicosus & & + & + \\
\hline Hygroamblystegium bumile & + & & \\
\hline Marchantia polymorpha & & + & + \\
\hline Philonotis caespitosa & & + & \\
\hline Polytrichum strictum & + & & \\
\hline Sphagnum capillifolium & + & & \\
\hline Sphagnum recurvum & + & & \\
\hline Tomentypnum nitens & + & + & + \\
\hline
\end{tabular}

the Bern Convention, the European Union Habitats and Species Directive, and in the Red data book of European bryophytes (ECCB 1995). In addition, it is a priority species of Natura 2000 wetlands. It is categorised as VU in Romania and Bulgaria, DD in Hungary without any currently existing population. In Serbia it has only two recently discovered localities, both of them in the southern part of the country. The population at Vlasina Lake is very small (PAPP et al. 2012), while in 2012 a larger population was found on the Pešter plateau (PAPP et al. 2014).

In Romania the following earlier localities are known (pers. comm. Irina Goia, Cluj-Napoca): Bistrita Nasaud County: Munții Țibleşului - Valea Mestecănişului, Valea Ţibleşului; Brasov County: mlaştina Hărman; Cluj County: Valea Someşului Cald- Bălceşti - Călățele, Masivul Vlădeasa - Vârfuraş, Micău, Rogojel; Covasna County: Comandău; Dimbovita County: Munții Leaota - Valea Vaca; Gorj County: Munții Parâng, Lacul Câlcescu; Harghita County: Depresiunea Giurgeu, Bazinul Ciucului, Mlaştina Pietroasa de la Joseni, Bazinul Gheorghieni; Hunedoara County: Munții Retezat - Tăul Judele; Sibiu County: Munții Făgăraş - Ucea Mare, Corabia; Suceava County: Codrul Secular Slătioara, Plaiul Todirescu, Pârâul Chiril, Valea Sâlhoasa Grădinița, Turbăria Coşna, Lucina; Muntele Rarău, Munții Călimani, Mlaştina eutrofică Drăgoioasa, Tinovul Găina - Lucina, Valea Stânii, Mlaştina Cristişor. 
Monitoring of Hamatocaulis vernicosus has been started in many localities, but information about the existing populations and results of the population monitoring are still not available.

In the Alcsík Basin we found the species at two sites. In Felső Honcsok wetland at Sînsimion (Csíkszentsimon) it has a population of ca 2-3 $\mathrm{m}^{2}$, while in Varsavész wetland at Tuşnadu Nou (Újtusnád) only a few individuals were found mixed in a patch of Tomentypnum nitens and Aulacomnium palustre. Both sites were known previously. In the Herbarium of the Hungarian Natural History Museum there are specimens collected by Ádám Boros on 20.07.1941 at Sînsimion (Csíkszentsimon) (Boros 1941). In the "Field diaries" he made a note on the species, stating that it is "abundant, nice". At Tuşnadu on the bank of river Olt he also collected a specimen on 04.08.1942 (Boros 1942).

\section{Bryophyte rarities}

To our knowledge of the bryoflora of SE Europe, the following species are rare or redlisted in Romania (ŞTEFĂNUȚ and GoIA 2012). Their threat status is commented on the basis of their red list status in the neighbouring countries and on our experiences.

Breidleria pratensis is a northern subcontinental (DüLL 1985) wetland species. It is not known from Hungary, and is CR in Bulgaria. Although it is not redlisted in Romania, it can be regarded as threatened, rare species in SE Europe. In the Alcsík Basin we collected it mixed with other species in the wetland near river Olt at Cetățuia (Csatószeg) and Kiscsemő wetland at Vrabia (Csíkverebes). Apparently, the populations are very small.

Bryum klinggraeffii is EN in Romania. Not redlisted in the neighbouring countries. This tiny Bryum species is overlooked, undercollected. Its high threat status in Romania is probably due to the limited research on the rhizoid gemmae bearing Bryum erythrocarpum complex, where this species belongs to.

Bryum radiculosum is $\mathrm{EN}$ in Romania. Not redlisted in the neighbouring countries. Being also a member of Bryum erythrocarpum complex, the same comments can be made as for the former Bryum species.

Campylium protensum is EN in Romania, VU in Bulgaria. The known records of this species resulted in a false picture about its distribution, as in the past (and even now), in many floristical works it is not separated from its close relative $C$. stellatum. Taking into account that $C$. stellatum is a frequent species and not redlisted in Romania, the high red list category of $C$. protensum should be re-evaluated after a careful taxonomic revision of herbarium specimens and future fieldworks, which would provide a clearer view about its distribution. 
Dicranella rufescens is VU in Romania. Not redlisted in the neighbouring countries. This tiny species of wet muddy soils is also overlooked, undercollected.

Drepanocladus polygamus is a boreal wetland species (DüLL 1985), VU in Romania and Bulgaria, and NT in Hungary. It is a threatened wetland species in SE Europe. In the Alcsík Basin we collected it in a spring cone at Sînsimion (Csíkszentsimon) and in the Nádasfürdő source area at Tuşnadu Nou (Újtusnád).

Grimmia laevigata is VU in Romania. Not redlisted in the neighbouring countries. This is a frequent Grimmia species of siliceous rocks. Its high-rank red list status reflects the limited knowledge on the genus Grimmia in Romania.

Grimmia mueblenbeckii is VU in Romania and Bulgaria. This is also a frequent species of siliceous rocks. Its high-rank red list status can be also attributed to the limited knowledge on genus Grimmia in Romania.

Philonotis marchica is a sub-Mediterranean species (DüLL 1985), NT in Romania, EN in Bulgaria. According to PAPP et al. (2010) it is DD in Hungary without any recent record, but not long ago it was also found in two localities. In Serbia, three recently located populations were found (PAPP and ERZBERGER 2005, 2007, 2009). In the Alcsík Basin we collected it at a source area at Tuşnad (Tusnád) from a small population.

Philonotis caespitosa is a boreal element (DüLL 1985), EN in Hungary, and VU in Bulgaria. In Serbia there are two recently known populations (PAPP and ERzBerger 2005, PAPP et al. 2004). Although this species is not redlisted in Romania, it is considered a rare wetland species in SE Europe. We found it in several wetlands in the Alcsík Basin; Borsáros at Sîncrăieni (Csíkszentkirály), Sînsimion (Csíkszentsimon), Tuşnadu Nou (Újtusnád), and Sîntimbru (Csíkszentimre). It usually occurs along rivulets, and at sources in the wetlands.

Plagiomnium elatum is a boreal moss (DüLL 1985), NT in Romania. Not redlisted in the neighbouring countries. It is a characteristic Plagiomnium species of wetlands, source areas. Its near threatened status in Romania seems to be an overestimation.

Plagiomnium ellipticum is a boreal species, VU in Romania, NT in Hungary. It is a rare wetland species, although in the Alcsík Basin it is a characteristic element of wet grasslands. Its populations are quite extensive.

Poblia melanodon is NE in Romania. This species of wet muddy soils is also among the overlooked, undercollected bryophytes in the country.

Scorpidium cossonii is CR in Romania. It has been recently separated from its close relative S. revolvens (HEDENÄs 2003). Its distribution should be clarified on the basis of taxonomic revision of herbarium specimens and future fieldworks. In the Alcsík Basin we found it in two wetland areas at Sînsimion (Csíkszentsimon) and Tuşnadu Nou (Újtusnád). 
Sphagnum subsecundum is NT in Romania, VU in Hungary and Serbia. It seems to be a rare species of its genus in SE Europe. In the Alcsík Basin we collected it in a small quantity in a wetland near Sîntimbru (Csíkszentimre).

Tomentypnum nitens is a boreal element (DüLL 1985), EN in Hungary, in Bulgaria and in Serbia. This is a rare wetland species in the neighbouring countries with only a few known existing populations (e.g. in Serbia only at Vlasina Lake (PAPP et al. 2012)). In Romania it is not redlisted. In the wetlands of the Alcsík Basin this is a characteristic and abundant species, which also reflects the high nature conservation value of this area.

Trichodon cylindricus is $\mathrm{VU}$ in Romania. Not redlisted in the neighbouring countries. This tiny plant of wet muddy soils is also overlooked, undercollected.

\section{CONCLUSIONS}

In spite of the small extension and reduced water supply of the wetland fragments found in the Alcsík Basin, the area still preserves very valuable bryophyte vegetation rich in elements characteristic for fens and mires. Such species are Breidleria pratensis, Dicranum bonjeanii, Drepanocladus polygamus, Philonotis marchica, P. caespitosa, Plagiomnium ellipticum, Polytrichum strictum, Scorpidium cossonii, Sphagnum spp., and Tomentypnum nitens. Some of these, such as Plagiomnium ellipticum, or Tomentypnum nitens, are very abundant and represent the largest populations currently known in SE Europe. The maintenance and assisted increase of the population sizes of these rare bryophytes would be a major goal of conservation efforts.

Based on our knowledge on the state of wetlands in SE Europe and our field experience, it may be stated that the main threat is the reduced water supply and recurring dry summers. Also, due to the changes in land use, large tracts of these areas became abandoned; without mowing the wetlands are often invaded by reed and pioneer shrubs (mainly Salix) or transformed into tall herb community, and their structure is getting denser. Under such circumstances the bryophytes cannot receive sufficient amounts of light and space to grow. It is fearful that especially the most valuable rarities will soon disappear, which are (or should be) in the focus of nature conservation. These rare species are adapted to oligotrophic conditions and low-growing vegetation with good water supply.

Another threatening factor is the wetland burning, which is a widely used management form in the basin. It physically destroys the bryophyte vegetation and may alter the oligotrophic condition towards mesotrophic.

To protect the bryophyte assemblages it is suggested that a June mowing is adequate, but mowing later in the summer can be harmful as it can lead to water loss and intensified drainage of the area. 
Acknowledgements - The work was supported by the "Plan de management şi campanie de informare, educare şi conştientizare pentru Situl Natura 2000 Bazinul Ciucului de Jos - cod proiect SMIS-CSNR36405" project. The authors are grateful to Krisztina Havadtői (Marosvásárhely/Tîrgu Mureş) for her help in the field survey.

Összefoglaló: 2013 nyarán egy a Natura 2000-es területek állapotát, biológiai sokféleségét felmérő projekt keretében az Alcsíki-medence mohászati vizsgálatát végeztük el. Egykor a mai Románia vizes területeinek, lápjainak 25\%-a ebben a 650-740 m tengerszint feletti magasságon fekvő medencében koncentrálódott. Mára csak töredéke maradt fenn e lápoknak, többségük mezőgazdasági területek közé ékelődött kis kiterjedésű maradvány, amelyek 2007 óta védettséget élveznek, mint Natura 2000-es területek. Az Alcsíki-medence mohaflórájáról az 1940-es évekből származnak korábbi adatok, az utóbbi időben felmérés nem történt.

Jelen vizsgálat során összesen 70 mohafajt ( 5 májmoha, 65 lombosmoha) sikerült kimutatni. Annak ellenére, hogy a vizes területek kis kiterjedésủek és vízellátottságuk sem kielégítő, még számos olyan lápi, lápréti mohafajnak adnak otthont, amelyek Délkelet-Európában ritkák, pl. Breidleria pratensis, Dicranum bonjeanii, Drepanocladus polygamus, Philonotis marchica, P. caespitosa, Plagiomnium ellipticum, Polytrichum strictum, Scorpidium cossonii, Sphagnum spp., Tomentypnum nitens. Ezek közül néhány (pl. Plagiomnium ellipticum, Tomentypnum nitens) gyakori, és igen nagy populációkat alkot a vizsgált területen. A legértékesebb megtalált mohafaj a Hamatocaulis vernicosus, amely szerepel a Berni Konvencióban, az Európai Unió Élőhelyvédelmi Irányelv listáján, valamint az Európai Moha Vörös Könyvben.

A ritka fajok számára az egyik fő veszélyeztető tényező a vízellátottság csökkenése, amely klimatikus okokra vezethető vissza (pl. száraz nyarak gyakoriságának növekedése). Veszélyeztető tényező a hagyományos földhasználat megváltozása is. A kaszálás elmaradása a lápréteken a nád és cserjék (pl. füzek) térhódítását idézi elő, ami a fényigényes, alacsony füvű láprétekhez alkalmazkodott mohák visszaszorulásával jár. A ritka, lápréti fajok megőrzése érdekében a területek kaszálása fontos lenne.

\section{REFERENCES}

Boros, Á. (1941): Florisztikai jegyzetek. [Field diaries]. - Manuscript, Hungarian Natural History Museum, Budapest.

Boros, Á. (1942): Florisztikai jegyzetek. [Field diaries]. - Manuscript, Hungarian Natural History Museum, Budapest.

Boros, Á. (1943a): Florisztikai jegyzetek. [Field diaries]. - Manuscript, Hungarian Natural History Museum, Budapest.

Boros, Á. (1943b): A Meesia hexasticha a Székelyföldön. [Meesia hexasticha in Szeklerland]. Scripta Bot. Mus. Transsilv. 2: 122-123.

Coldea, GH. and Plămadă, E. (1977): Contribuții la studiul Cl. Scheuchzerio-Caricetea fuscae în România IV. - Contr. Bot. 17: 69-78.

DÜLL, R. (1985): Distribution of the European and Macaronesian mosses (Bryophytina) II. - Bryol. Beiträge 5: 110-232.

ECCB (1995): Red data book of European bryophytes. - European Committee for Conservation of Bryophytes, Trondheim, $291 \mathrm{pp}$.

Gergely, I. and RaȚiU, F. (1973): Vegetaţia mlaştinilor eutrofe din bazinul superior al Ciucului. - Contr. Bot. 13: 143-165. 
Gergely, I., Hodişan, I. and Groza, Gh. (1988): Contribuții la cunoaşterea vegetaţiei perturbate din depresiunea inferioară a Ciucului (Jud. Harghita). - Contr. Bot. 28: 25-49.

Grolle, R. and Long, D. G. (2000): An annotated check-list of the Hepaticae and Anthocerotae of Europe and Macaronesia. - J. Bryol. 22(2): 103-140. http://dx.doi.org/10.1179/jbr.2000.22.2.103

Hedenäs, L. (2003): The European species of the Calliergon-Scorpidium-Drepanocladus complex, including some related or similar species. - Meylania 28: 1-116.

Hill, M. O., Bell, N., Bruggeman-Nannenga, M. A., Brugués, M., Cano, M. J., Enroth, J., Flatberg, K. I., Frahm, J.-P., Gallego, M. T., Garilleti, R., Guerra, J., Hedenäs, L., Holyoak, D. T., Hyvönen, J., Ignatov, M. S., Lara, F., Mazimpaka, V., Muñoz, J. and SÖDERSTRÖM, L. (2006): An annotated checklist of the mosses of Europe and Macaronesia. - J. Bryol. 28(3): 198-267. http://dx.doi.org/10.1179/174328206X119998

Ignatov, M. S., Afonina, O. M., Ignatova, E. A. et al. (2006): Check-list of mosses of East Europe and North Asia. - Arctoa 15: 1-130.

IsoviıtA, P. (1966): Studies on Sphagnum L. I. Nomenclatural revision of the European taxa. Ann. Bot. Fennici 3: 199-264.

JAKAB, G., Csergö, A.-M. and Ambrus, L. (2007): A Székelyföld flórakutatásának története. (Review on the floristic research of Szeklerland (Romania)). - Flora Pannonica 5: 105-133.

KeREKES, Sz. (2010): Az Alcsíki-medence lápjainak botanikai állapotfelmérése és vegetációváltozásainak vizsgálata. [Survey on the botanical state and vegetation change of the mires of Alcsík Basin]. - Manuscript, PhD thesis, University of West Hungary, Sopron-Csíkszereda.

KRISTó, A. (1958): Plantele rare şi relicte ce trebuie ocrotite în mlaştinile de la Sâncrăieni "Borsáros". - Ocrot. Nat. 3: 154-157.

Mititelu, D. and Sántha-Elekes, E. (1984): Vegetația rezervațiilor botanice de la Sâncrăieni. Muz. Ist. Nat. Iaşi, vol. Festiv. 1984: 123-128.

Natcheva, R., Ganeva, A. and Spiridonos, G. (2006): Red list of the bryophytes in Bulgaria. Phytol. Balcan. 12(1): 55-62.

NyÁRÁdy, E. Gy. (1929): A vizek és vizben bövelkedö talajok növényzetéröl a Hargitában. - In: Csutak, V. (ed.): Emlékkönyv a Székely Nemzeti Múzeum 50 éves jubileumára. Székely Nemzeti Múzeum, Sepsiszentgyörgy, pp. 557-615.

PAPp, B. and ERzBerger, P. (2005): The bryophyte flora of Golija-Studenica Biosphere Reserve and some adjacent sites (SW Serbia, Serbia-Montenegro). - Studia bot. hung. 36: 101-116.

PAPP, B. and ERZBERger, P. (2007): Contributions to the bryophyte flora of Western Stara Planina Mts (E. Serbia). - Studia bot. hung. 38: 95-123.

PAPp, B. and ERzBerger, P. (2009): Contributions to the bryophyte flora of southeastern Serbia: Suva Planina Mts and its surroundings. - Studia bot. hung. 40: 125-142.

Papp, B., ERZberger, P., Ódor P., Hoch, Zs., SZÖvényi, P., SZURdoki, E. and Tóth, Z. (2010): Updated checklist and red list of Hungarian bryophytes. - Studia bot. hung. 41: 31-59.

Papp, B., Erzberger, P. and Sabovljević, M. (2004): Contributions to the bryophyte flora of Kopaonik Mts (Serbia, Serbia-Montenegro). - Studia bot. hung. 35: 67-79.

Papp, B., Szurdoki, E. and Sabovljević, M. (2012): Bryophyte flora of Lake Vlasina and its surroundings (SE Serbia). - Studia bot. hung. 43: 27-45.

Papp, B., Szurdoki, E., Pantović, J. and Sabovljević, M. (2014): Contributions to the bryophyte flora of the Pešter plateau, SW Serbia. - Studia bot. hung. 45: 33-47.

http://dx.doi.org/10.17110/StudBot.2014.45.33

Pop, E. (1938): Rezervaţia ştiinţifică de la Sîncrăieni. - Bul. Com. Mon. Nat. 6: 9-10.

Pop, E. (1960): Mlastinile de turbă din Republica Populară Romînă. - Ed. Acad. Republicii Populare Romîne, Bucureşti, 511 pp. 
Rațiv, F. (1980): Problema ocrotirii genofondului floristic al județului Harghita. - Acta Hargitensia 1: 433-442.

RaȚiU, F. and Gergely, I. (1974): Asociații vegetale noi şi rare pentru țara noastră. - Stud. Univ. Babeş-Bolyai Ser. Biol. 19(1): 7-15.

RaȚiU, F. and Gergely, I. (1975a): Aspecte de dinamică perturbată în mlaştinile eutrofe din Bazinul mijlociu al Ciucului. - Aluta (Sepsiszentgyörgy) 6-7: 473-478.

RaŢıU, F. and Gergely, I. (1975b): Aspecte de vegetaţie din mlaştinile eutrofe ale bazinului mijlociu al Ciucului. - Contr. Bot. 15: 105-115.

RaŢiU, F. and Gergely, I. (1981): Fitocenoze caracteristice mlaştinilor eutrofe din bazinul inferior al Ciucului. - Contr. Bot. 21:59-83.

Sabovljević, M., Cvetić, T. and STEvanović, V. (2004): Bryophyte red list of Serbia and Montenegro. - Biodiversity and Conservation 13: 1781-1790. http://dx.doi.org/10.1023/B:BIOC.0000029338.97776.66

Smith, A. J. E. (2004): The moss flora of Britain and Ireland. - University Press, Cambridge, 739 pp. ŞTEFĂNUT,, S. and GoiA, I. (2012): Checklist and red list of bryophytes of Romania. - Nova Hedwigia 95(1-2): 59-104. http://dx.doi.org/10.1127/0029-5035/2012/0044

(submitted: 19.01 .2015 , accepted: 15.08 .2015 )

Appendix 1. Complete list of bryophyte records.

The numerals following the species names refer to the collection sites described in Material and Methods under site details.

\section{Liverworts}

Aneura pinguis (L.) Dumort. - 1, 12, 20: in wetland Lophocolea bidentata (L.) Dumort. - 12: at a source Lophocolea heterophylla (Schrad.) Dumort. - 2: soil

Marchantia polymorpha L. subsp. polymorpha - 1, 3, 4, 5, 12, 20: in wetland; 19: soil; 21: at a source Pellia endiviifolia (Dicks.) Dumort. - 12: in wetland; 21: at a source

\section{Mosses}

Abietinella abietina (Hedw.) M. Fleisch. - 18: soil

Amblystegium serpens (Hedw.) Schimp. - 1: in wetland and on bark of Salix; 2: bark of Betula; 3, 17: in wetland; 14: wall of a bridge

Atrichum undulatum (Hedw.) P. Beauv. - 1: in wetland

Aulacomnium palustre (Hedw.) Schwägr. - 1, 3, 4, 5, 8, 9, 10, 11, 12, 17, 20, 22: in wetland; 19: soil Barbula convoluta Hedw. - 14: soil

Brachytheciastrum velutinum (Hedw.) Ignatov et Huttunen - 18: on volcanic rock

Brachythecium mildeanum (Schimp.) Schimp. - 1: in wetland and on bark of Salix; 5, 9, 11, 12, 15, 17, 20: in wetland; 7, 19: soil

Brachythecium rivulare Schimp. - 12: in wetland and at a source

Brachythecium rutabulum (Hedw.) Schimp. - 1, 3, 5, 8, 17, 20: in wetland; 2: bark of tree; 21: at a source

Brachythecium salebrosum (Hoffm. ex F. Weber et D. Mohr) Schimp. - 21: on decaying wood Breidleria pratensis (W. D. J. Koch ex Spruce) Loeske - 19: on soil; 20: in wetland 
Bryum argenteum Hedw. - 18: on volcanic rock Bryum klinggraeffi Schimp. - 1: bank of river Olt

Bryum pseudotriquetrum (Hedw.) P. Gaertn. et al. - 1, 3, 4, 5, 10, 11, 15, 17, 20, 22: in wetland; 7, 19: soil; 12: in wetland and at a source

Bryum radiculosum Brid. - 18: on soil

Calliergonella cuspidata (Hedw.) Loeske - 1, 3, 4, 5, 8, 9, 11, 12, 15, 17, 20: in wetland; 13, 14, 19: soil; 21: at a source

Campylium protensum (Brid.) Kindb. - 12: in wetland

Campylium stellatum (Hedw.) Lange et C. E. O. Jensen - 4, 5, 20: in wetland

Ceratodon purpureus (Hedw.) Brid. - 5: in wetland; 18: on volcanic rock

Cirriphyllum piliferum (Hedw.) Grout - 22: in wetland

Climacium dendroides (Hedw.) F. Weber et D. Mohr - 1, 4, 5, 9, 10, 11, 16, 17, 20, 22: in wetland

Cratoneuron filicinum (Hedw.) Spruce - 7: soil; 12: in wetland and at a source; 15: in wetland

Dicranella rufescens (Dicks.) Schimp. - 14: on soil

Dicranella varia (Hedw.) Schimp. - 12: at a source

Dicranum bonjeanii De Not. - 17: in wetland; 19: on soil

Didymodon rigidulus Hedw. - 14: on wall of a bridge support

Didymodon tophaceus (Brid.) Lisa - 12: at a source

Drepanocladus aduncus (Hedw.) Warnst. - 1, 3, 4, 5, 8, 12, 15, 17, 20: in wetland; 6, 7, 13, 14, 19: soil; 21: at a source

Drepanocladus polygamus (Schimp.) Hedenäs - 7: soil; 12: in wetland

Fissidens adianthoides Hedw. - 11, 12, 20, 22: in wetland; 19: on soil

Funaria hygrometrica Hedw. - 18: on soil

Grimmia laevigata (Brid.) Brid. - 18: on volcanic rock

Grimmia muehlenbeckii Schimp. - 18: on volcanic rock

Grimmia ovalis (Hedw.) Lindb. - 18: on volcanic rock

Hamatocaulis vernicosus (Mitt.) Hedenäs - 4, 11: in wetland

Hedwigia ciliata (Hedw.) P. Beauv. - 18: on volcanic rock

Homomallium incurvatum (Schrad. ex Brid.) Loeske - 18: on volcanic rock

Hygroamblystegium humile (P. Beauv.) Vanderp., Goffinet et Hedenäs - 2: on artificial stonewall of the source

Hypnum cupressiforme Hedw. - 18: on volcanic rock

Leptobryum pyriforme (Hedw.) Wilson - 2: on soil and on artificial stonewall of the source; 3: in wetland

Leptodictyum riparium (Hedw.) Warnst. - 9, 15, 20: in wetland; 13: on soil; 21: at a source

Orthotrichum pumilum Sw. ex anon. - 2: bark of Betula

Palustriella falcata (Brid.) Hedenäs - 12: in wetland and at a source

Paraleucobryum longifolium (Hedw.) Loeske - 18: on volcanic rock

Phascum cuspidatum Hedw. - 18: on soil

Philonotis caespitosa Jur. $-1,8,11,17$ : in wetland

Philonotis marchica (Hedw.) Brid. - 21: at a source

Plagiomnium cuspidatum (Hedw.) T. J. Kop. - 2: on soil; 8, 17: in wetland; 18: on volcanic rock Plagiomnium elatum (Bruch et Schimp.) T. J. Kop. - 5, 10, 11, 15, 17, 20, 22: in wetland; 19: on soil Plagiomnium ellipticum (Brid.) T. J. Kop. - 1, 3, 4, 5, 17, 20: in wetland; 21: at a source

Plagiomnium undulatum (Hedw.) T. J. Kop. - 2: on soil

Platygyrium repens (Brid.) Schimp. - 18: on volcanic rock

Pohlia melanodon (Brid.) A. J. Shaw - 1: bank of river Olt; 14: on soil

Poblia wahlenbergii (F. Weber et D. Mohr) A. L. Andrews - 21: at a source

Polytrichum strictum Menzies ex Brid. - 1: in wetland 
Pterigynandrum filiforme Hedw. - 18: on volcanic rock

Sciuro-hypnum populeum (Hedw.) Ignatov et Huttunen - 2: bark of tree; 18: on volcanic rock Scorpidium cossonii (Schimp.) Hedenäs - 5, 12: in wetland

Sphagnum angustifolium (C. E. O. Jensen ex Russow) C. E. O. Jensen - 1: in wetland

Sphagnum capillifolium (Ehrh.) Hedw. - 1: in wetland

Sphagnum palustre L. - 17: in wetland

Sphagnum subsecundum Nees - 17: in wetland

Thuidium assimile (Mitt.) A. Jaeger - 11, 16, 17: in wetland; 19: on soil

Tomentypnum nitens (Hedw.) Loeske - 1, 3, 4, 5, 8, 9, 11, 12, 17, 20, 22: in wetland; 19: on soil Trichodon cylindricus (Hedw.) Schimp. - 12: at a source 